\title{
De vordering van de benadeelde partij in het strafproces: de Hoge Raad geeft college
}

\author{
Bijdrage naar aanleiding van het overzichtsarrest van de Hoge Raad van 28 mei 2019, \\ ECLI:NL:HR:2019:793
}

\author{
Mr. A.J.J.G. Schijns*
}

\begin{abstract}
1. Inleiding
Op 28 mei 2019 heeft de Hoge Raad een belangrijk overzichtsarrest gewezen over de vordering van de benadeelde partij in het strafproces. De feiten in de zaak die in cassatie voorlag, zijn overzichtelijk. Het Gerechtshof Arnhem-Leeuwarden heeft verdachte bij arrest van 19 januari 2017 veroordeeld wegens medeplegen van hennepteelt in de door verdachte gehuurde woning, en voor het medeplegen van diefstal van elektriciteit door middel van verbreking van de woning en beschadiging van de woning. Daarnaast heeft het hof beslissingen genomen ten aanzien van de vordering van de benadeelde partij, waarbij een groot deel daarvan (een bedrag van $€ 20.269,72$ ) is toegewezen ter vergoeding van de zaakschade. Het hof heeft daarbij gebruik gemaakt van zijn bevoegdheid ex artikel 6:97 van het Burgerlijk Wetboek (BW) om de schade te schatten, omdat niet iedere schadepost nauwkeurig kon worden vastgesteld. Enkele schadeposten waren gebaseerd op schattingen van de herstelkosten. Ter weerlegging van het verweer van verdachte dat de schade om die reden niet in het strafproces kon worden beoordeeld, heeft de benadeelde gesteld dat hij tot dan toe nog geen geld heeft gehad om alle schade te repareren en dat 'hij het verschrikkelijk zou vinden om opnieuw een civiele procedure op te starten om deze kosten te verhalen'. Het door de verdachte ingestelde cassatieberoep bevatte slechts één middel, dat erover klaagt dat het hof ten onrechte de afwijzing van het namens verdachte gevoerde verweer ter zake de hoogte van de vordering benadeelde partij dan wel de schadevergoedingsmaatregel niet van een nadere motivering heeft voorzien.
\end{abstract}

De Hoge Raad heeft dit cassatiemiddel aangegrepen om college te geven over tal van aandachtspunten die bij de beoor-

Mr. A.J.J.G. Schijns is advocaat bij Beer advocaten te Amsterdam en onderzoeker aan de Vrije Universiteit Amsterdam. Zij doet promotieonderzoek naar de compensatie van misdrijfschade. deling van de vordering van de benadeelde partij een rol kunnen spelen. Het gaat daarbij om

1. uitleg van bepalingen uit het Wetboek van Strafvordering (Sv) en het Wetboek van Strafrecht (Sr) (rechtstreekse schade en schadevergoedingsmaatregel);

2. toelichting op de beoordeling en beslissing door de rechter (het civiele bewijsrecht);

3. toelichting op civielrechtelijke begrippen in relatie tot de strafprocedure (begroting van vermogensschade, hoofdelijke aansprakelijkheid, wettelijke rente, proceskosten, shockschade en verplaatste schade).

De opbouw van deze bijdrage is als volgt. In paragraaf 2 bespreek ik de door de Hoge Raad geschetste juridische kaders en aandachtspunten die van belang zijn voor de beoordeling van de vordering van de benadeelde partij. In paragraaf 3 ga ik in op het belang van de uitspraak en op de vraag waarom de Hoge Raad vond dat zo'n uitvoerige uiteenzetting nodig was. Ik bespreek daar ook dat de uiteenzetting door de Hoge Raad op sommige punten weer nieuwe vragen oproept, en de deur opent voor creatieve vorderingen en procestactiek.

\section{De door de Hoge Raad geschetste juridische} kaders

\subsection{Strafrechtelijk kader: uitleg van bepalingen uit het Sren $S v$}

\subsubsection{Rechtstreekse schade}

Ten eerste besteedt de Hoge Raad aandacht aan het begrip rechtstreekse schade (art. 51 lid 1 Sv en art. 361 lid 2 aanhef en onder b Sv). De benadeelde partij kan in het strafproces vergoeding vorderen van de schade die door een strafbaar feit is geleden indien tussen het bewezenverklaarde handelen van de verdachte en de schade voldoende verband bestaat om te kunnen aannemen dat de benadeelde partij door dit handelen 
rechtstreeks schade heeft geleden. De Hoge Raad overweegt als volgt:

'2.3.1 Voor de beantwoording van de vraag of zodanig verband bestaat zijn de concrete omstandigheden van het geval bepalend. Voor het aannemen van zodanig verband is niet vereist dat de schade betrekking heeft op voorwerpen die in de bewezenverklaring zijn vermeld. Evenmin geldt met betrekking tot vermogensdelicten als bovengrens aan de schadevergoeding het bedrag dat de verdachte door het bewezenverklaarde misdrijf heeft verworven. Voorts is niet vereist dat de benadeelde partij is getroffen in een belang dat door de overtreden strafbepaling rechtstreeks wordt beschermd.'

Vervolgens benoemt de Hoge Raad enkele voorbeelden in de rechtspraak waarin sprake was van schade die rechtstreeks door een strafbaar feit is geleden (r.o. 2.3.2). Zo zijn de reparatiekosten van een fiets die een slachtoffer voorafgaand aan een mishandeling had laten vallen, aan te merken als rechtstreekse schade. Ook door een benadeelde partij gederfd loon vanwege het opnemen van een vrije dag na een inbraak in haar woning geldt als schade die rechtstreeks door het strafbare feit is geleden. Een ander voorbeeld is het geld dat is opgenomen nadat de verdachte de bankpas van de benadeelde partij had gestolen. Voorts is niet (langer) vereist dat de benadeelde partij is getroffen in een belang dat door de overtreden strafbepaling rechtstreeks wordt beschermd. Naar aanleiding van deze overwegingen analyseerden Felix en Schild de verhouding tussen het strafrechtelijke begrip rechtstreekse schade in relatie tot het civielrechtelijke vereiste van causaal verband (in de zin van art. 6:98 BW). ${ }^{1}$ Het is goed, en volgens hen ook noodzakelijk, beide begrippen van elkaar te onderscheiden. Het rechtstreeks verband ziet op de strafvorderlijke causaliteit en is een ontvankelijkheidsvereiste voor de vordering van de benadeelde partij in het strafproces. Het civielrechtelijke causaliteitsvereiste is van belang voor de inhoudelijke beoordeling van de vordering, in het bijzonder voor de vraag welke schade (nog) kan worden toegerekend aan de onrechtmatige gedragingen van de verdachte. De onderstreping door de Hoge Raad van de twee vereisten zal in de praktijk verhelderend werken, al zal over de nadere invulling van deze vereisten nog veelvuldig worden geprocedeerd. Zie ter illustratie over het civielrechtelijk causaal verband de recente uitspraak van de Hoge Raad in de zaak van het schietincident in Alphen aan den Rijn, en de onder dat arrest verschenen annotatie elders in dit nummer. ${ }^{2}$

\subsubsection{Schadevergoedingsmaatregel}

Ook aan de schadevergoedingsmaatregel wijdt de Hoge Raad enkele principiële overwegingen:

1. I. Felix \& A. Schild, Rechtstreekse schade en causaal verband bij de vordering van de benadeelde partij in het strafproces, NJB 2019, afl. 23, p. $1654-1662$.

2. I. Haazen onder HR 20 september 2019, ECLI:NL:HR:2019:1409 (schietincident Alphen aan den Rijn).
'Uit de bewoordingen alsmede de geschiedenis van de totstandkoming van art. 36f Sr volgt dat de in die bepaling bedoelde maatregel een strafrechtelijke sanctie is die los van de beslissing in de voegingsprocedure kan worden opgelegd. De schadevergoedingsmaatregel kan door de rechter ook worden opgelegd indien het slachtoffer geen schadevergoeding heeft gevorderd of niet in zijn vordering kan worden ontvangen. Hieruit volgt ook dat de rechter niet is gehouden het bedrag van de betalingsverplichting als bedoeld in art. 36f Sr op hetzelfde bedrag te stellen als het bedrag waarvoor hij de daarmee verband houdende vordering van de benadeelde partij heeft toegewezen.' (r.o. 2.9.2)

In paragraaf 3.2.4 ga ik nader in op de mogelijkheden die deze overweging voor de praktijk biedt.

\subsection{Het kader van het civiele bewijsrecht}

$\mathrm{Bij}$ de beoordeling van de vordering van de benadeelde partij moet de rechter de civiele processuele regels en waarborgen in acht nemen. Op het civiele bewijsrecht gaat de Hoge Raad uitvoerig in. Eerst wordt vastgesteld dat op de vordering van de benadeelde partij niet de bewijs(minimum)regels gelden van het $\mathrm{Sv}$, maar de regels van stelplicht en bewijslastverdeling in civiele zaken. De Hoge Raad plaatst de hoofdregels van de artikelen 149 en 150 van het Wetboek van Burgerlijke Rechtsvordering $(\mathrm{Rv})$ in de context van het strafproces:

'In de context van het strafproces heeft die stelplicht in het bijzonder betrekking op de feiten en omstandigheden die niet kunnen worden vastgesteld aan de hand van uit het strafdossier af te leiden gegevens met betrekking tot het aan de verdachte tenlastegelegde strafbare feit, hetgeen in het bijzonder geldt voor feiten en omstandigheden die bepalend zijn voor de aard en omvang van de gevorderde schade.' (r.o. 2.8.1)

Ook vraagt de Hoge Raad aandacht voor de consequentie van het onbetwist laten door de verdediging van de feiten die aan de vordering ten grondslag zijn gelegd. Artikel $149 \mathrm{Rv}$ bewegwijzert in dat geval naar toewijzing van de vordering, tenzij de vordering ongegrond of onrechtmatig overkomt. In het strafproces geldt echter als bijkomend uitgangspunt dat toewijzing eveneens achterwege blijft als de rechter door de beperkingen van het strafproces niet verzekerd acht dat beide partijen in voldoende mate in de gelegenheid zijn geweest hun stellingen en onderbouwingen met betrekking tot de toewijsbaarheid genoegzaam naar voren te brengen. In dat geval zal de rechter de benadeelde partij in haar vordering niet-ontvankelijk moeten verklaren (r.o. 2.8.3).

\subsection{Het civielrechtelijke schadevergoedingsrecht in relatie tot de strafprocedure}

Bij de beoordeling van de vordering van de benadeelde partij moet de strafrechter niet alleen aandacht hebben voor de formele civielrechtelijke regels, maar ook voor de juiste toepassing 
van het materiële civiele recht. In zijn beschouwing bespreekt de Hoge Raad een aantal (kern)begrippen van het aansprakelijkheids- en schadevergoedingsrecht, over de uitleg en toepassing waarvan in het strafproces nogal eens misverstand kan rijzen.

\subsubsection{Concrete en abstracte schadebegroting en schatting van de omvang van de schade}

Eerst wordt toegelicht hoe de rechter vermogensschade (art. 6:96 BW) kan begroten, waarbij ingegaan wordt op het uitgangspunt van concrete schadebegroting en de mogelijkheid van abstracte schadebegroting (r.o. 2.4.2).

Vervolgens benadrukt de Hoge Raad dat de omvang van de schade kan worden geschat als zij niet nauwkeurig kan worden begroot (art. 6:97 BW) (r.o. 2.4.2). Deze overweging vormt tevens de basis voor de verwerping van het cassatieberoep: het oordeel van het hof dat bepaalde nog te maken (herstel)kosten zijn geschat, staat niet in de weg aan toewijzing van die kosten, is toereikend en niet onbegrijpelijk gemotiveerd (r.o. 3.4).

Benadeelde partijen dienen zich te realiseren dat de mogelijkheid van schatting van de omvang van de schade ook een risico kan inhouden. Indien de rechter namelijk met gebruikmaking van zijn schattingsbevoegdheid de vordering tot een bepaald bedrag heeft toegewezen, impliceert die beslissing de afwijzing van hetgeen meer werd gevorderd. De vordering is dan voor het afgewezen deel 'verdampt': dat deel kan niet meer aan de civiele rechter worden voorgelegd. Dit is slechts anders als uit de beslissing blijkt van een splitsing van de vordering in een deel waarvan de behandeling geen onevenredige belasting van het strafgeding oplevert, en een deel dat de benadeelde aan de burgerlijke rechter kan voorleggen (r.o. 2.8.7 jo. r.o. 2.8.4).

\subsubsection{Vaststelling van schade en aansprakelijkheid}

Met betrekking tot de redelijke kosten ter vaststelling van schade en aansprakelijkheid (art. 6:96 lid 2 BW) merkt de Hoge Raad onder meer het volgende op:

'2.4.3 Als vermogensschade komen ingevolge art. 6:96, tweede lid, BW, mede voor vergoeding in aanmerking:

(...)

b. redelijke kosten ter vaststelling van schade en aansprakelijkheid, waaronder ook zijn begrepen de kosten die de benadeelde partij heeft gemaakt om het gepleegde strafbare feit aan het licht te brengen;

(...)

Onder vermogensschade in de hiervoor bedoelde zin zijn echter niet begrepen de door een benadeelde partij gemaakte kosten voor rechtsbijstand; deze zijn te rekenen tot de hierna te bespreken proceskosten waaromtrent de rechter ingevolge art. 592a Sv in de daar bedoelde gevallen een afzonderlijke beslissing dient te geven.' (curs. AS)

Verderop in deze bijdrage ga ik nader op dit onderwerp in, waarbij ook het onderscheid aan de orde komt tussen proces- kosten en kosten ter vaststelling van schade en aansprakelijkheid (par. 3.2.3 en 3.2.1).

\subsubsection{Immateriële schade; aantasting in de persoon}

Vervolgens besteedt de Hoge Raad aandacht aan de immateriele schade, in het bijzonder de categorie van 'aantasting in de persoon op andere wijze' als bedoeld in artikel 6:106 aanhef en onder b BW. Nadat is uiteengezet in welke gevallen aanspraak kan worden gemaakt op vergoeding van immateriële schade, komt de Hoge Raad aan bij de vraag wat een 'aantasting in de persoon op andere wijze' inhoudt. Daarvan is in ieder geval sprake indien de benadeelde partij geestelijk letsel heeft opgelopen, dat naar objectieve maatstaven moet worden vastgesteld. Om te vervolgen met een herhaling van de belangrijkste overwegingen uit het EBI-arrest eerder dit jaar: ${ }^{3}$

'Ook als het bestaan van geestelijk letsel in voornoemde zin niet kan worden aangenomen, is niet uitgesloten dat de aard en ernst van de normschending en van de gevolgen daarvan voor de benadeelde, meebrengen dat van de in art. 6:106, aanhef en onder b, BW bedoelde aantasting in zijn persoon "op andere wijze" sprake is. In zo een geval zal degene die zich hierop beroept de aantasting in zijn persoon met concrete gegevens moeten onderbouwen. Dat is slechts anders indien de aard en de ernst van de normschending meebrengen dat de in dit verband relevante nadelige gevolgen daarvan voor de benadeelde zo voor de hand liggen, dat een aantasting in de persoon kan worden aangenomen. Van een aantasting in de persoon "op andere wijze" als bedoeld in art. 6:106, aanhef en onder b, BW, is niet reeds sprake bij de enkele schending van een fundamenteel recht.' (r.o. 2.4.5)

\subsubsection{Affectieschade en verplaatste schade}

Dan vervolgt de Hoge Raad met overwegingen over affectieschade en verplaatste schade. Relevant is vooral de vaststelling dat de wijziging van artikel $51 \mathrm{f}$ lid $2 \mathrm{~Sv}$ meebrengt dat derden zich met ingang van 1 januari 2019 in het strafproces kunnen voegen ter zake van de kosten die zij ten behoeve van het slachtoffer hebben gemaakt, de zogenoemde 'verplaatste schade' als bedoeld in artikel 6:107 lid 1 onder a BW. Het gaat dan om de kosten die het slachtoffer, als niet de derde maar hijzelf deze zou hebben gemaakt, van de verdachte had kunnen vorderen. Met de wetswijziging en de heldere overweging van de Hoge Raad op dit punt staat buiten kijf dat verplaatste schade (gewoon) in het strafproces kan worden gevorderd. De discussie die plaatsvond in de zaak tegen Robert M., waar het hof de vorderingen van de ouders van de misbruikte minderjarige kinderen tot vergoeding van reiskosten en vervanging van meubilair niet had toegewezen omdat het ging om verplaatste schade, behoort daarmee tot de verleden tijd. ${ }^{4}$

3. HR 15 maart 2019, ECLI:NL:HR:2019:376 (EBI).

4. HR 16 september 2014, ECLI:NL:HR:2014:2668 (Robert M.); het toegewezen bedrag aan proceskosten was $€ 95.307,57$. 
De Hoge Raad maakt duidelijk dat niet alleen derden vergoeding van deze schade kunnen vorderen, maar dat het slachtoffer zelf dat ook kan:

'De omstandigheid dat art. 6:107 BW aan derden een eigen recht op schadevergoeding toekent terzake van "verplaatste schade" en de thans op grond van art. 51f, tweede lid, Sv bestaande mogelijkheid voor die derden om zich terzake te voegen in het strafproces, doen overigens niet af aan de bevoegdheid van het slachtoffer om, als benadeelde partij, ook zelf vergoeding van deze schade te vorderen. Bij een en ander verdient aantekening dat, indien de verdachte de schade heeft vergoed aan de derde die de kosten daadwerkelijk heeft gemaakt, hij in zoverre ook tegenover het slachtoffer is bevrijd en omgekeerd.' (r.o. 2.4.8) (curs. AS)

Nieuw is deze overweging niet, ${ }^{5}$ maar zij zal in de praktijk onnodig debat en misvattingen voorkomen over de vraag aan wie de vordering toekomt.

\subsubsection{Wettelijke rente}

De Hoge Raad onderstreept dat ook wettelijke rente overeenkomstig de bepalingen van het BW in het strafproces kan worden gevorderd, maar plaatst ook een caveat: net als in een civiele procedure kan wettelijke rente alleen worden toegewezen als die is gevorderd (r.o. 2.5). Waar het in het civiele proces einde oefening is als vergoeding van de rente niet is meegevorderd, biedt het strafrecht nog een ontsnappingsroute via de schadevergoedingsmaatregel. Het feit dat vergoeding van de wettelijke rente niet is gevorderd, staat namelijk niet in de weg aan het vermeerderen van de op grond van artikel $36 \mathrm{f}$ Sr opgelegde betalingsverplichting (schadevergoedingsmaatregel) met de wettelijke rente (r.o. 2.5 en 2.9.2).

\subsubsection{Hoofdelijke aansprakelijkheid}

In strafzaken komt het nogal eens voor dat meerdere personen betrokken zijn bij een misdrijf. Denk aan een gewelddadige roofoverval die is beraamd door een groep, terwijl niet alle leden van de groep bij de overval aanwezig zijn. Denk ook aan een mishandeling in groepsverband, waarbij niet kan worden vastgesteld wie de fatale schop of klap heeft gegeven. Het komt ook wel eens voor dat sommige van de verdachten nog niet zijn geïdentificeerd of gearresteerd. De Hoge Raad ziet daarin aanleiding om enkele uitgangspunten over hoofdelijkheid (art. 6:102 BW) toe te lichten, en daarbij te vermelden dat ook gedragingen van een medeplichtige grondslag kunnen vormen voor diens hoofdelijke aansprakelijkheid (r.o. 2.6). Wel zal dan in de toewijzing van de vordering en ook bij de schadevergoedingsmaatregel in het dictum tot uitdrukking moeten komen dat sprake is van hoofdelijkheid, teneinde duidelijk te maken 'dat de door de wet aan hoofdelijkheid verbonden gevolgen - waaronder de bevrijding van de schuldenaar in

5. HR 5 december 2008, ECLI:NL:HR:2008:BE9998, NJ 2009/387 m.nt. Vranken (Rijnstate), r.o. 3.7. geval van betaling door een medeschuldenaar (art. 6:7, tweede lid, BW) - intreden' (r.o. 2.6).

\subsubsection{Proceskosten}

Ook aan het thema van de proceskosten heeft de Hoge Raad enkele overwegingen gewijd. Zo is herhaald dat de begroting van de proceskosten een feitelijke beslissing is die geen motivering behoeft, en dat de kosten van rechtsbijstand niet zijn aan te merken als schade die rechtstreeks is geleden door het strafbare feit. Proceskosten kunnen om die reden ook niet worden meegenomen bij de oplegging van de schadevergoedingsmaatregel als bedoeld in artikel $36 f \mathrm{fr}$ (r.o. 2.7.1-2.7.2). Verder worden de proceskosten van de benadeelde partij in het strafproces begroot volgens dezelfde maatstaf als in het civiele proces, namelijk het liquidatietarief zoals is neergelegd in het op rechtspraak.nl gepubliceerde 'Liquidatietarief rechtbanken en hoven'. Hieronder (in par. 3.2.3) kom ik nader over dit onderwerp te spreken.

\section{Het belang van het overzichtsarrest}

Hoewel de vordering in deze zaak uitsluitend zag op vergoeding van zaakschade, is de uitspraak (juist) ook relevant voor vorderingen tot vergoeding van personenschade in het strafproces. Het belang van de uitspraak zit in meerdere aspecten.

\subsection{Het oogmerk van het arrest: bevorderen van schadeloosstelling via een eenvoudige procedure}

Ten eerste springt het doel van het overzichtsarrest in het oog. Wat beoogde de Hoge Raad met deze uitvoerige uiteenzetting waartoe het ingestelde cassatiemiddel niet noopte? ${ }^{6}$ De Hoge Raad geeft zelf antwoord op die vraag door het 'grote belang' te onderstrepen 'dat benadeelde partijen erbij hebben op een eenvoudige wijze schadeloos gesteld te worden voor de schade die zij door een strafbaar feit hebben geleden' (r.o. 2.1). In dezelfde overweging had de Hoge Raad al aangegeven dat de wetgever met de mogelijkheid tot het instellen van een vordering binnen het strafproces heeft beoogd te voorzien in een 'eenvoudige en laagdrempelige procedure die ertoe leidt dat personen die schade hebben geleden als gevolg van een strafbaar feit zoveel mogelijk schadeloos worden gesteld' (r.o. 2.1). Die regelgeving is niet effectief als in de praktijk veel vorderingen sneuvelen omdat onnodig de niet-ontvankelijkheid wordt uitgesproken omdat de behandeling van de vordering een onevenredige belasting van het strafgeding zou opleveren. Met de uitvoerige uiteenzetting wil de Hoge Raad dan ook 'voorkomen dat de strafrechter vaker dan nodig gebruik maakt van zijn bevoegdheid' een benadeelde partij in haar vordering niet-ontvankelijk te verklaren omdat deze te onevenredig belastend zou zijn (r.o. 2.1). Dit is een belangrijke overweging, omdat de Hoge Raad daarmee de conclusies lijkt te onderkennen van het WODC-onderzoek uit 2016, waaruit blijkt dat complexe (letselschade)vorderingen vaak niet-ontvankelijk worden verklaard, met het argument dat deze een onevenredi-

6. De Hoge Raad verwerpt het cassatiemiddel met een pennenstreek (r.o. 3.4), na maar liefst negen overwegingen te hebben gewijd aan de zaakoverstijgende vragen. 
ge belasting van het strafproces vormen (art. 361 lid 3 Sv). ${ }^{7}$ Het overzichtsarrest moet rechters beter in staat stellen de complexe afwegingen te maken die vorderingen binnen het strafproces kunnen meebrengen. Daartoe is volgens de Hoge Raad des te meer aanleiding nu met ingang van 1 januari 2019 de wet is uitgebreid met de mogelijkheid van verhaal van verplaatste schade binnen het strafproces en met de mogelijkheid van vergoeding van affectieschade. ${ }^{8}$

\subsection{Bevordering rechtseenheid}

Het belang van het arrest zit ten tweede in de uitleg en nadere afbakening van een aantal begrippen uit het materiële en formele civiele recht en strafrecht die bij de beoordeling van de vordering van de benadeelde partij vaak een rol spelen. Het overzichtsarrest draagt daardoor bij aan de uniformiteit en voorspelbaarheid van de rechtspraak. Dat is winst, omdat de indruk bestaat dat beslissingen over de vordering sterk verschillen per gerecht en per rechter. Het gaat dan niet alleen om verschillen tussen strafrechters, maar ook om verschillen in beslissingen tussen civiele rechters enerzijds en strafrechters anderzijds. In juli van dit jaar deed Slachtofferhulp Nederland een oproep aan rechters om de hoogte van toegekende bedragen aan smartengeld beter te onderbouwen, omdat de onderlinge verschillen in vergelijkbare zaken 'onaanvaardbaar' groot zijn. ${ }^{9}$ De verschillen lijken zich ook voor te doen bij het oordeel of de vordering een onevenredige belasting voor het strafproces meebrengt. Er zijn rechtbanken die hun hand niet omdraaien voor een complexe vordering over derving van levensonderhoud, terwijl dergelijke vorderingen bij andere rechterlijke colleges niet inhoudelijk worden beoordeeld vanwege een onevenredige belasting. ${ }^{10}$ Het overzichtsarrest zal niet al deze verschillen kunnen wegnemen, maar de uitleg van enkele begrippen, en de plaatsing daarvan in de context van het strafproces (zoals de Hoge Raad heeft gedaan met zijn overwegingen over hoofdelijke aansprakelijkheid, vergoeding van immateriële schade bij een aantasting in de persoon op andere wijze en verplaatste schade), zal ongetwijfeld bijdragen aan meer rechtseenheid. Toch roept de uiteenzetting door de Hoge Raad op sommige punten weer nieuwe vragen op, en zet deze de deur open voor creatieve vorderingen en procestactiek. Ik licht een aantal onderwerpen uit.

\subsubsection{Kosten van private opsporing}

Ten eerste de overweging van de Hoge Raad dat onder de kosten ter vaststelling van schade en aansprakelijkheid (art. 6:96 lid 2 onder $\mathrm{b}$ BW) ook begrepen moeten worden de kosten die

7. R.S.B. Kool e.a., Civiel schadeverhaal via het strafproces. Een verkenning van de rechtspraktijk en regelgeving betreffende de voeging benadeelde partij, Den Haag: WODC 2016, p. 149, 246-247, 254-256 en 258-259.

8. Wet affectieschade, wet van 11 april 2018, Stb. 2018, 132.

9. Zie www.slachtofferhulp.nl/nieuws/2019/onaanvaardbare-verschillenbij-smartengeld/.

10. Deze indruk is gebaseerd op de ervaring van de auteur in de praktijk, die wordt bevestigd door andere slachtofferadvocaten. Zie hierover ook 'Recordschadevergoeding, advocaten: grabbelton', de Volkskrant 15 oktober 2019, en 'Snel de schade vergoed krijgen is lot uit de loterij', NRC Handelsblad 26 oktober 2019. de benadeelde partij heeft gemaakt 'om het gepleegde strafbare feit aan het licht te brengen'. De Hoge Raad heeft dat al eens eerder overwogen, en verwijst daar in zijn recente overzichtsarrest naar. ${ }^{11}$ In die zaak ging het om kosten die de benadeelde partij (een verzekeraar) had gemaakt voor het laten verrichten van onderzoek door een schadebureau naar de juistheid van een schademelding. Ook had de verzekeraar kosten gemaakt voor het doen van aangifte. Beide kostenposten komen op de voet van artikel 6:96 lid 2 onder b BW voor vergoeding in aanmerking, aldus hof en Hoge Raad in 2008. Borgers heeft in zijn noot onder het arrest opgemerkt dat de uitspraak erop neerkomt dat de kosten van particuliere recherche in beginsel kunnen worden verhaald op degene die het strafbare feit dat aanleiding tot die recherche heeft gegeven, heeft begaan. ${ }^{12} \mathrm{Hij}$ plaatste destijds vraagtekens bij de rechtvaardiging daarvoor, zeker in het licht van de omstandigheid dat de kosten van het strafvorderlijke onderzoek van overheidswege niet verhaalbaar zijn. De verwijzing in het onderhavige overzichtsarrest naar dit arrest uit 2008 doet vermoeden dat de Hoge Raad niettemin vasthoudt aan de eerder uitgezette lijn. De vingerwijzing uit 2008 heeft, voor zover ik kan overzien, in het strafproces niet geleid tot een stroom aan vorderingen tot vergoeding van de kosten van particuliere recherche. De nadruk die de Hoge Raad nu op de vergoedbaarheid van deze kosten legt, kan daar verandering in brengen. Het biedt immers mogelijkheden voor benadeelden of nabestaanden die zelf onderzoek laten verrichten naar bijvoorbeeld de toedracht of oorzaak van het ontstane letsel of het overlijden. De door de Hoge Raad gekozen formulering voor de vergoedbaarheid van de kosten ('het aan het licht brengen van een strafbaar feit') doet vermoeden dat de Hoge Raad hierbij in ieder geval denkt aan kosten die voorafgaand aan het doen van aangifte zijn gemaakt. Maar is het daartoe ook beperkt? Hoe zit het bijvoorbeeld met de kosten die een slachtoffer maakt voor een onderzoek nadat het Openbaar Ministerie de zaak geseponeerd heeft, en welk onderzoek is relevant voor een artikel 12 Sv-procedure? Dit was aan de orde in een zaak waarin een jonge vrouw was overleden als gevolg van ernstig schedel- en hersenletsel nadat zij door haar partner op het hoofd was geslagen met een bowlingkegel. ${ }^{13}$ Het Openbaar Ministerie wilde de zaak seponeren omdat het noodweerverweer van de verdachte hem plausibel voorkwam. De nabestaanden hebben een medisch deskundigenbericht laten opstellen over de aannemelijkheid van het beroep op noodweer in het licht van het medisch dossier en het ontstane letsel. Ik meen dat de door de nabestaanden gemaakte kosten voor dit deskundigenonderzoek ook aan te merken zijn als kosten die verband houden met het aan het licht brengen van het strafbare feit.

11. HR 22 april 2008, ECLI:NL:HR:2008:BB7077, NJ 2008/468 m.nt. Borgers.

12. HR 22 april 2008, ECLI:NL:HR:2008:BB7077, NJ 2008/468 m.nt. Borgers, sub 1.

13. De auteur heeft de nabestaanden van de overledene bijgestaan in de strafprocedure die is gevolgd op de art. $12 \mathrm{~Sv}$-procedure. 
En hoe zit het met de kosten tijdens de opsporings- en vervolgingsfase? Ook dan kunnen slachtoffers en nabestaanden behoefte hebben aan eigen onderzoek ('policing the police'). Dit was bijvoorbeeld het geval in de zaak van Mitch Henriquez, waar de nabestaanden zelf onderzoek hadden ingesteld naar de vraag of de door de politie toegepaste nekklem de oorzaak van zijn overlijden was, althans zo valt af te leiden uit de uitspraak van het Gerechtshof Den Haag. ${ }^{14}$ De door de nabestaanden in de strafprocedure ingestelde vordering tot vergoeding van deze particuliere onderzoekskosten is door het hof grotendeels niet-ontvankelijk verklaard. Het hof wijdt geen principiële overweging aan de vraag of deze kosten moeten worden begrepen onder 'het aan het licht brengen van het strafbare feit', maar bepaalt dat het maken van deze kosten niet 'redelijkerwijs noodzakelijk' was. Het hof zal bij dat oordeel vermoedelijk hebben meegenomen dat er al rapporten beschikbaar waren die afkomstig waren van het strafvorderlijk onderzoek dat van overheidswege was uitgevoerd. Mijn indruk is dat het debat in rechte over deze schadepost in het strafproces nog maar aan het begin staat van een ontwikkeling.

\subsubsection{Rechtstreekse schade}

De Hoge Raad heeft in het overzichtsarrest (nogmaals) duidelijk gemaakt dat voor de beoordeling of sprake is van 'rechtstreekse schade' (art. 51 lid 1 en 361 lid 2 aanhef en onder b Sv) niet vereist is dat iemand is getroffen in een belang dat door de overtreden strafbepaling wordt beschermd..$^{15}$ Door deze 'relativiteitseis' los te laten, en erop te wijzen dat de concrete omstandigheden van het geval bepalend zijn voor het antwoord op de vraag of er rechtstreekse schade is, maakt de Hoge Raad het zowel voor de benadeelde partij makkelijker om vergoeding van bepaalde kosten te vorderen, als voor de rechter om deze toe te wijzen.

\subsubsection{Proceskosten}

Op het punt van de proceskosten levert de beoordeling door de Hoge Raad ook nieuwe vragen op. In het arrest is het beginsel gehandhaafd dat de proceskosten aan de kant van de benadeelde partij moeten worden begroot overeenkomstig het gebruikelijke liquidatietarief, net als in civiele zaken. Wel biedt de overweging over de proceskosten uitdrukkelijk ruimte voor afwijking van het liquidatietarief, doordat de Hoge Raad onderstreept dat het gaat om een niet-bindende richtlijn, die 'zich bovendien niet steeds [leent] voor directe toepassing op de door de raadsman verrichte werkzaamheden ten behoeve van de benadeelde partij die zich in het strafproces heeft gevoegd' (r.o. 2.7.3).

In de zaak tegen Robert M. leidde toepassing van deze bevoegdheid vanwege 'de uitzonderlijke aard en omvang van de zaak' tot toewijzing van een fors hoger bedrag aan proceskosten dan het liquidatietarief. ${ }^{16}$ Er zijn mij niet veel andere

14. Hof Den Haag 19 juni 2019, ECLI:NL:GHDHA:2019:1532, r.o. 155. 15. HR 5 juni 2016, ECLI:NL:HR:2016:1522, NJ 2016/335.

16. HR 16 september 2014, ECLI:NL:HR:2014:2668 (Robert M.); het toegewezen bedrag aan proceskosten was $€ 95.307,57$. zaken bekend waarin de rechter aanleiding heeft gezien af te wijken van het liquidatietarief. Recent nog heeft het Gerechtshof Den Haag het verzoek van de nabestaanden van de overleden arrestant Mitch Henriquez om een hogere proceskostenveroordeling afgewezen. ${ }^{17}$ Een andere route om (een deel van) de daadwerkelijk gemaakte advocaatkosten vergoed te krijgen, is die van artikel 6:96 BW. Deze route wordt (nog) niet veel bewandeld, maar heeft recent erkenning gevonden in de uitspraak in de zaak tegen Jawed S. (aanslag Amsterdam CS), waarin de Rechtbank Amsterdam een bedrag aan advocaatkosten heeft toegewezen voor werkzaamheden die betrekking hadden op de vaststelling van (de omvang van) de schade. ${ }^{18}$ De rechtbank heeft deze kosten onderscheiden van de kosten wegens rechtsbijstand (zoals het bijwonen van de zittingen). Is hier een precedent geschapen?

Een andere vraag die partijen nogal eens verdeeld houdt, is die naar de samenloop tussen een kostenveroordeling en een aan de procederende partij verleende toevoeging. Al eerder dit jaar heeft de Hoge Raad uitgemaakt dat een toevoeging niet in de weg staat aan een kostenveroordeling. ${ }^{19}$ Wel merkt de Hoge Raad terecht op dat de Raad voor Rechtsbijstand de proceskostenveroordeling in beginsel in mindering brengt op de aan de rechtsbijstandsverlener toekomende toevoegingsvergoeding.

Voor de praktijk ook uitermate relevant is de overweging van de Hoge Raad dat een niet-ontvankelijkverklaring van de vordering op de grond dat deze een onevenredige belasting van het strafproces oplevert, niet zonder meer meebrengt dat een proceskostenveroordeling achterwege blijft en de benadeelde partij zelf de kosten moet dragen. Dat lijkt mij een terecht uitgangspunt. De niet-ontvankelijkverklaring vanwege een onevenredige belasting brengt immers niet mee dat de benadeelde partij de in het ongelijk gestelde partij is. ${ }^{20}$ Haar vordering is eenvoudigweg niet beoordeeld in het strafproces. Deze overweging is in lijn met eerdere rechtspraak. ${ }^{21} \mathrm{Wel}$ onderstreept de Hoge Raad dat als de rechter in zo'n geval de verdachte veroordeelt in de proceskosten, die beslissing dan wel motivering behoeft (r.o. 2.7.4). ${ }^{22}$ Dat kan de rechter voor lastige vragen stellen, bijvoorbeeld als hij op basis van de strafrechtelijke veroordeling tot het oordeel komt dat een vergoedingsplicht bestaat, maar dat hij de omvang daarvan in het strafproces niet kan bepalen. Is de benadeelde partij in dat geval de in het gelijk gestelde partij ${ }^{23}$ En hoe zit het in de situatie dat een deel van de vordering niet-ontvankelijk is ver-

17. Hof Den Haag 19 juni 2019, ECLI:NL:GHDHA:2019:1532, r.o. 155.

18. Rb. Amsterdam 14 oktober 2019, ECLI:NL:RBAMS:2019:7566, r.o. 6.4.4.2.

19. HR 19 januari 2019, ECLI:NL:HR:2019:87 ('shaken baby').

20. Vgl. F.F. Langemeijer, Het slachtoffer in het strafproces, Deventer: Kluwer 2010, p. 116.

21. HR 16 september 2014, ECLI:NL:HR:2014:2668, NJ 2015/71 m.nt. Keulen (Robert M.), r.o. 2.3.

22. Zoals al eerder was benadrukt in HR 23 november 2010, ECLI:NL:HR: 2010:BM9405, NJ 2011/223.

23. Zie ook Keulen in zijn noot onder HR 16 september 2014, ECLI:NL:HR:2014:2668, NJ 2015/71 (Robert M.), sub 7. 
klaard, maar dat een ander deel van de vordering met gebruikmaking van de schattingsbevoegdheid wel gedeeltelijk is toegewezen, maar ook gedeeltelijk is afgewezen $?^{24}$ Het komt nogal eens voor dat de benadeelde partij ervoor kiest een verzoek om een proceskostenveroordeling achterwege te laten. De reden daarvan is vaak gelegen in het feit dat een processueel debat over deze vragen vaak meer kost dan dat het oplevert. Niet alleen omdat de proceskosten volgens het gematigde liquidatietarief worden beoordeeld, maar ook omdat de benadeelde met een proceskostenveroordeling in de meeste gevallen niets opschiet. De proceskosten worden immers niet aangemerkt als schade, waardoor deze niet onder de schadevergoedingsmaatregel vallen. De benadeelde zal deze kosten zelf bij de verdachte moeten incasseren, wat in de meeste gevallen bij gebrek aan verhaalsmogelijkheden niet lukt. Het achterwege laten van een verzoek om een kostenveroordeling voorkomt echter niet dat de rechter zich over deze vragen moet buigen. Het opnemen van een kostenveroordeling in de beslissing is een ambtshalve verplichting van de rechter (art. 592a jo. art. 361 lid 6 Sv). Dat geldt niet alleen voor de proceskosten van de benadeelde partij die zich heeft gevoegd in het strafproces, maar ook voor de kosten van de verdachte, die hij heeft gemaakt om zich te verweren tegen de vordering. Hoe met de laatstgenoemde kosten om te gaan is een vraag die de Hoge Raad in het overzichtsarrest niet heeft geadresseerd, en die in de praktijk (als ik het goed zie) nog geen rol van betekenis speelt. De kosten van de verdachte voor het voeren van verweer tegen de vordering worden vrijwel altijd op nihil begroot. De verwachting is evenwel dat dit zal veranderen als de vordering in het strafproces vaker dan nu inhoudelijk zal worden beoordeeld. Dat zal in ieder geval gebeuren als het consultatievoorstel Innovatiewet Strafvordering wet wordt. ${ }^{25}$ Het consultatievoorstel voorziet in de mogelijkheid dat de strafrechter de vordering al in een vroeg stadium van het strafproces loskoppelt van de strafzaak, indien deze een onevenredige belasting meebrengt. De vordering wordt dan na het eindvonnis in de strafzaak door een aparte (meervoudige) kamer van de rechtbank beoordeeld, waarin ook civilisten zitting kunnen nemen. ${ }^{26} \mathrm{Bij}$ de behandeling van complexe vorderingen in een dergelijk civiel kader ligt het voor de hand dat de verdachte kosten maakt die specifiek verband houden met de behandeling van de vordering. Dan zal de vraag over de omvang van de proceskostenveroordeling aan de zijde van verdachte naar verwachting vaker dan nu het geval is onderwerp van debat worden.

24. A-G Jörg heeft in zijn conclusie voor HR 23 november 2010, ECLI:NL:HR:2010:BM9405, NJ 2011/223, geprobeerd handvatten te geven voor een antwoord op deze vragen.

25. Wijziging van het Wetboek van Strafvordering ter bevordering van de innovatie van verschillende onderwerpen in het kader van de modernisering van het Wetboek van Strafvordering (Innovatiewet Strafvordering), www.internetconsultatie.nl/innovatiewet.

26. Zie nader over de afgesplitste procedure A.J.J.G. Schijns, Voorstel Innovatiewet Strafvordering: slachtoffers van misdrijven teruggeworpen in de tijd, NJB 2019 (nog te verschijnen)

\subsubsection{Schadevergoedingsmaatregel ook mogelijk bij niet- ontvankelijkheid}

Artikel 36f Sr bepaalt dat de strafrechter aan de verdachte de verplichting kan opleggen tot betaling aan de Staat van een geldbedrag ten behoeve van het slachtoffer indien en voor zover de verdachte jegens het slachtoffer naar burgerlijk recht aansprakelijk is voor de schade die door het strafbare feit is toegebracht (de schadevergoedingsmaatregel). Meestal lopen toewijzing van de civiele vordering en oplegging van de schadevergoedingsmaatregel samen, maar dat is niet noodzakelijk. De schadevergoedingsmaatregel kan ook worden opgelegd als de vordering om formele redenen niet-ontvankelijk is. De Hoge Raad heeft de mogelijkheid van oplegging van de schadevergoedingsmaatregel ondanks niet-ontvankelijkheid van de benadeelde partij in eerdere rechtspraak bevestigd, onder verwijzing naar de eigen aard van de schadevergoedingsmaatregel als strafrechtelijke sanctie, die losstaat van de beslissing in de voegingsprocedure. ${ }^{27}$ Ondanks deze vaste rechtspraak van de Hoge Raad is de vraag of oplegging van de schadevergoedingsmaatregel in deze gevallen mogelijk is nogal eens onderwerp van partijdebat. Het is om die reden goed dat de Hoge Raad (nogmaals) uitleg geeft over de verhouding tussen en de aard van de schadevergoedingsmaatregel en de civiele vordering:

'Uit de bewoordingen alsmede de geschiedenis van de totstandkoming van art. 36f $\mathrm{Sr}$ volgt dat de in die bepaling bedoelde maatregel een strafrechtelijke sanctie is die los van de beslissing in de voegingsprocedure kan worden opgelegd. De schadevergoedingsmaatregel kan door de rechter ook worden opgelegd indien het slachtoffer geen schadevergoeding heeft gevorderd of niet in zijn vordering kan worden ontvangen. Hieruit volgt ook dat de rechter niet is gehouden het bedrag van de betalingsverplichting als bedoeld in art. 36f $\mathrm{Sr}$ op hetzelfde bedrag te stellen als het bedrag waarvoor hij de daarmee verband houdende vordering van de benadeelde partij heeft toegewezen.' (r.o. 2.9.2)

Zo beschouwd kan de schadevergoedingsmaatregel goedmaken wat de (belangenbehartiger van de) benadeelde partij heeft laten liggen. Zo werden schadevergoedingsmaatregelen opgelegd terwijl de benadeelde partij niet-ontvankelijk was in haar vordering, omdat deze voor het eerst in appel was ingesteld, of voor schadeposten waarmee de vordering in hoger beroep was vermeerderd. ${ }^{28}$ Ook voor een vordering waarin de benadeelde partij niet kon worden ontvangen vanwege het ontbreken van vertegenwoordigingsbevoegdheid, is de schade-

27. HR 13 juli 2010, ECLI:NL:HR:2010:BM0912 (oplegging schadevergoedingsmaatregel bij een civielrechtelijk verjaarde vordering); HR 5 juli 2011, ECLI:NL:HR:2011:BQ5730, NJ 2011/329 (vordering niet-ontvankelijk omdat deze in hoger beroep niet was gehandhaafd; toch schadevergoedingsmaatregel); HR 11 oktober 2016, ECLI:NL:HR: 2016:2304, NJ 2017/90 m.nt. Keulen (vordering niet-ontvankelijk vanwege faillissement van de verdachte; toch schadevergoedingsmaatregel).

28. Hof Leeuwarden 10 september 2010, ECLI:NL:GHLEE:2010: BN6889; Hof Den Haag 1 juni 2017, ECLI:NL:GHDHA:2017:2540; Hof Amsterdam 20 september 2017, ECLI:NL:GHAMS:2017:3783. 
vergoedingsmaatregel opgelegd. ${ }^{29}$ In het onderhavige arrest onderstreept de Hoge Raad dat ook als de wettelijke rente niet is meegevorderd (en deze dus niet kan worden toegewezen), de rechter voor het bedrag van de wettelijke rente wel de schadevergoedingsmaatregel kan opleggen (r.o. 2.9.2).

De schadevergoedingsmaatregel kan ook goede diensten bewijzen als de vordering al door de civiele rechter is beoordeeld en toegewezen. De benadeelde partij kan dan niet meer worden ontvangen in haar vordering in het strafproces, maar het staat niet in de weg aan het opleggen van de schadevergoedingsmaatregel ter hoogte van de door de civiele rechter toegewezen vordering. ${ }^{30}$ Dit opent de weg naar tactisch procederen voor de benadeelde partij: in een civielrechtelijke procedure (mits tijdig voor de strafzaak afgerond) kan de schade worden begroot, waarna aan de strafrechter wordt gevraagd voor dat bedrag de schadevergoedingsmaatregel op te leggen. Van een onevenredige belasting van het strafproces is dan geen sprake meer, en het slachtoffer krijgt via de schadevergoedingsmaatregel en de daaraan gekoppelde voorschotregeling de schade daadwerkelijk vergoed. Deze route veronderstelt wel een snelle civiele rechtsgang, bijvoorbeeld in deelgeschil, of met gebruikmaking van de verkorte civiele procedure, zoals is voorzien in het rolreglement van de Rechtbank Amsterdam. ${ }^{31}$

\subsubsection{Shockschade}

In het spoor van de overweging die de Hoge Raad wijdt aan vergoeding van immateriële schade wegens een aantasting in de persoon 'op andere wijze' merkt het college op dat vergoeding van immateriële schade wegens een dergelijke aantasting ook kan plaatsvinden als sprake is van shockschade (r.o. 2.4.5). Door shockschade alleen in verbinding te brengen met immaterieel nadeel zou de indruk kunnen ontstaan dat de Hoge Raad ervan uitgaat dat bij shockschade alleen het immateriële nadeel voor vergoeding in aanmerking komt, terwijl inmiddels algemeen wordt aanvaard dat wanneer sprake is van shockschade ook de daardoor ontstane materiële schade tot de in beginsel te vergoeden schadeposten behoort. ${ }^{32}$ Ik meen dat de Hoge Raad hier niet heeft bedoeld een beperking aan te brengen. Dat het college alleen rept over immaterieel nadeel valt eerder toe te schrijven aan de plaats in het betoog waarop shockschade aan bod komt: namelijk onder het kopje 'Ander nadeel'. Meer moet er mijns inziens niet in worden gelezen. De Hoge Raad heeft overigens de overweging uit eerdere rechtspraak herhaald, dat een vordering tot vergoeding van shockschade niet op voorhand als een onevenredige belasting moet worden beschouwd, zodat een inhoudelijke beoordeling

29. Hof Den Haag 5 september 2017, ECLI:NL:GHDHA:2017:2519.

30. Rb. Zeeland-West-Brabant 4 mei 2016, ECLI:NL:RBZWB:2016:2666.

31. Zie het 'Procesreglement verkorte procedure' op rechtspraak.nl: www.rechtspraak.nl/SiteCollectionDocuments/procesreglementverkorte-procedure-handel-rechtbank-amsterdam-042019.pdf.

32. S.D. Lindenbergh, Smartengeld tien jaar later, Deventer: Kluwer 2009, p. 54; S.D. Lindenbergh, 'Affectieschade' en 'shockschade', onderscheid, samenloop en vooruitblik, TVP 2018, p. 143; Rb. Rotterdam 16 december 2015, ECLI:NL:RBROT:2015:9882, JA 2016/45 m.nt. Franke, r.o. 4.14 . van een shockschadevordering in het strafproces, mits goed onderbouwd, mogelijk is. ${ }^{33}$ Of dit aanleiding zal geven tot tactisch procederen (shockschadevordering bij de strafrechter aanbrengen in plaats van bij de civiele rechter), zal afhangen van de uniformiteit die strafrechters en civiele rechters weten te bereiken als het gaat om de uitleg van de Taxibus-criteria. Op basis van lagere rechtspraak zou het vermoeden kunnen ontstaan dat het confrontatiecriterium, althans tot voor kort, door de strafrechter iets soepeler wordt uitgelegd dan door de civiele rechter. Zo oordeelde de strafkamer van het Gerechtshof Amsterdam dat confrontatie van een moeder met het lichaam van haar door een geweldsmisdrijf overleden zoon in het mortuarium voldoende was voor toewijzing van een vordering tot vergoeding van shockschade. ${ }^{34}$ Daarentegen vond de sector civiel van de Rechtbank Rotterdam in een zaak waarin een meisje was overleden na een aanrijding met een vuilnisauto, dat confrontatie van de ouders met hun overleden dochter in het mortuarium niet voldoende was om voor vergoeding van shockschade in aanmerking te komen. ${ }^{35}$ In beide situaties waren de door het misdrijf respectievelijk het ongeval toegebrachte verwondingen zichtbaar. Inmiddels is de laatstgenoemde uitspraak in hoger beroep vernietigd, en kwam de civiele kamer van het Gerechtshof Den Haag tot het oordeel dat met de waarneming in het mortuarium wél voldaan is aan de confrontatie-eis als bedoeld in het Taxibus-arrest. ${ }^{36} \mathrm{Het}$ hof hechtte daarbij belang aan de omstandigheid dat moet worden aangenomen dat de ouders zich bij die identificatie 'een duidelijk en concreet beeld hebben kunnen vormen van de omstandigheden waaronder het slachtoffer is overleden en de gevolgen daarvan'. Deze bewoordingen vertonen een opvallende gelijkenis met de bewoordingen waarin de strafkamer van het Gerechtshof Arnhem-Leeuwarden twee weken voor de uitspraak van het Gerechtshof Den Haag de shockschadevordering van de ouders en broer van Anne Faber toewees. Ook daar had confrontatie plaatsgevonden in het mortuarium, en in het geval van de broer via foto's van het lichaam van zijn zus. ${ }^{37}$ De door hen ingediende shockschadevorderingen werden toegewezen, waarbij het hof met betrekking tot de confrontatie van de broer overwoog dat het onvermijdelijk is dat hij zich een voorstelling heeft kunnen maken van wat zijn zus is aangedaan en van de toestand waarin zijn zus zich na het geweld en de levensberoving bevond'. Zoeken strafrechter en civiele rechter hier aansluiting bij elkaar? Dat zou de rechtseenheid zeer ten goede komen.

\subsection{Civiele expertise bij de beoordeling van de vordering benadeelde partij}

Het derde belang van de uitspraak van de strafkamer van de Hoge Raad schuilt in het feit dat zij mede gewezen is door twee raadsheren uit de civiele kamer van de Hoge Raad. Daar-

33. R.o. 2.8.7, waar is verwezen naar HR 27 september 2016, ECLI:NL:HR 2016:2201.

34. Hof Amsterdam 26 juni 2018, ECLI:NL:GHAMS:2018:2091.

35. Rb. Rotterdam 4 oktober 2017, ECLI:NL:RBROT:2017:8894

36. Hof Den Haag 23 juli 2019, ECLI:NL:GHDHA:2019:1901.

37. Hof Arnhem-Leeuwarden 5 juli 2019, ECLI:NL:GHARL:2019:5542. 
mee neemt de Hoge Raad (bij mijn weten voor het eerst) het initiatief tot een al eerder bepleit systeem, waarbij een civielrechtelijk onderlegde rechter of raadsheer wordt toegevoegd aan de strafkamer als een (complexe) vordering benadeelde partij voorligt. Dit voorbeeld verdient navolging, waarmee we als het aan de minister ligt al op korte termijn kunnen experimenteren, als het voorstel tot behandeling van de complexe vordering in een afgesplitste procedure tot wet wordt. ${ }^{38}$

38. Wijziging van het Wetboek van Strafvordering ter bevordering van de innovatie van verschillende onderwerpen in het kader van de modernisering van het Wetboek van Strafvordering (Innovatiewet Strafvordering), www.internetconsultatie.nl/innovatiewet; A.J.J.G. Schijns, Voorstel Innovatiewet Strafvordering. Misdrijfslachtoffers van klapluik naar valluik, NJB 2019, afl. 34, p. 2502-2505. 